\title{
THE PUBLIC POLICY EXCEPTION UNDER THE NEW YORI CONVENTION ON THE RECOGNITION AND ENFORCEMENT OF FOREIGN ARBITRAL AWARDS (THE UK PERSPECTIVE)
}

\begin{abstract}
One of the main purposes of the New York Convention ${ }^{1}$ was to serve international trade and commerce and to make it easier to enforce an arbitral award made in one Contracting State in other states. Nonetheless, Article $V(2)(b)$ permits the judge not to give effect to an award if its enforcement would be contrary to public policy. In the $21^{\text {st }}$ century, the courts in England are more reluctant to refuse the enforcement of foreign arbitral awards under $s 68(2)(g)$ or s103(3) of the Arbitration Act $1996^{2}$. As a result, the law surrounding the public policy exception has become more predictable because the "pro enforcement bias" of the New York Convention has been more faithfully observed. However, in other developed European states such as Switzerland, Hungary, Austria, and Germany, courts have taken a more interventionist stance in recent years.
\end{abstract}

Keywords

public policy - exception - New York Convention

\footnotetext{
* Currently a PhD Candidate at the Jagiellonian University. Also graduated with LLB Law (Hons) from University of Northampton and was awarded "Certificate of Commendation from the University of Northampton Law Board of Study for the Outstanding Academic Achievement" and won "Shoosmiths prize for Outstanding Contribution to Corporate Responsibility 2014". He also completed LLM with LPC (Legal Practice Course) at the University of Law, London; e-mail: bart.orawiec@gmail.com.

1 New York Convention on the Recognition and Enforcement of Foreign Arbitral Awards of 10.06 .1958 .

$2 \quad \mathrm{~S} 68(2)(\mathrm{g})$ lists "public policy" grounds as an example of a serious irregularity; the court may set an award aside. The court may also refuse to recognise or enforce an arbitral award under s103(3) if such recognition or enforcement would be contrary to public policy.
} 


\section{INTRODUCTION}

Arbitration has become increasingly popular in international commercial contracts and is widely regarded as the preferred method of resolving international commercial disputes. Parties may be compelled to enter into arbitration agreements because, as opposed to litigation, international arbitration provides a speedy, neutral, and confidential dispute resolution process mostly subject to the parties' control ${ }^{3}$. "The idea of arbitration is that of binding resolution of disputes accepted with serenity by those who bear its consequences because of their special trust in chosen decision-makers" 4 . However, the reality is that not all international arbitral awards are voluntarily complied with.

International arbitral awards are given legal effect by a developed legal framework of both international and national sources ${ }^{5}$. On an international level, the main convention which addresses the substantive aspects of enforcement of arbitral awards is the New York Convention on the Recognition and Enforcement of Foreign Arbitral Awards (New York Convention) of 10 June $1958^{6}$. On a national level, arbitration statutes provide substantive criteria for enforcing awards and procedural mechanisms ${ }^{7}$.

The New York Convention is an established and successful international agreement, which made a number of significant improvements in the regime of the Geneva Protocol 1923 and Geneva Convention 19278. One of its main purposes was to make it easier to enforce an arbitral award made in one Contracting State in other states 9 It not only eliminated the "double exequatur" requirement ${ }^{10}$ for arbitral

\footnotetext{
3 G. Born, International Arbitration: Law and Practice, the Netherlands 2012, pp. 9-16.

J. Paulsson, The Idea of Arbitration, Oxford 2013, p. 1.

G. Born, International Commercial Arbitration, vol. II, the Netherlands 2009, p. 2334.

M. Mcilwrath, J. Savage, International Arbitration and Mediation, the Netherlands 2010, p. 345 .

7 Born, supra note 3, p. 275.

8 L. Mistelis, S. Brekoulakis, Arbitrability: International \& Comparative Perspectives, the Netherlands 2009, p. 85.

9 Born, supra note 5, p. 2336.

10 The requirement necessitated the confirmation of an award in the courts of the arbitral seat (first "exequatur") before it could be recognised abroad (second "exequatur").
} 
awards, but also imposed a general obligation on Contracting States to recognise and enforce arbitral awards ${ }^{11}$, proposed a limited set of grounds for non-recognition of an international arbitral award in Article V, and limited the places in which an arbitral award may be annulled ${ }^{12}$.

Article V of the New York Convention lists limited grounds for nonrecognition of foreign arbitral awards. These include claims that the arbitration agreement is not valid; that the losing party was not given proper notice; that the arbitral award deals with a dispute beyond the scope of the parties' arbitration agreement; that the composition of the arbitral authority or its procedures were not in accordance with the parties' arbitration agreement; that the award is not capable of settlement by arbitration; or that the enforcement or the recognition of the award would be contrary to the public policy of the enforcing state ${ }^{13}$.

The purpose of the public policy exception is to permit the judge not to give effect to an award which would be contradictory to the fundamental principles of the judge's social system ${ }^{14}$. The term "public policy" is ambiguous owing to its multiplicity of possible meanings; it is usually defined by reference to the moral, political, or economic order of the state, or to basic notions of justice and morality ${ }^{15}$. Burroughs $\mathrm{J}$ said that, "Public policy - it is an unruly horse and when once you get astride it, you never know where it will carry you. It may lead you from the sound law. It is never argued at all but when other points fail"16. Hence he argued that a public policy exception leads to unpredictable outcomes and it would only be used if all the other options available to the party were

\footnotetext{
11 Article III of the New York Convention requires Contracting States to recognise foreign arbitral awards no more onerous than those for domestic awards.

12 Born, supra note 5, pp. 2334-2336.

13 Article $\mathrm{V}(1)(\mathrm{a})(\mathrm{b})(\mathrm{c})(\mathrm{d})(\mathrm{e})$ and $\mathrm{V}(2)$ of the New York Convention on the Recognition and Enforcement of Foreign Arbitral Awards of 10.06.1958; G. Born, International Arbitration and Forum Selection Agreements: Drafting and Enforcing, the Netherlands 2013, pp. 156-158.

14 G. Cordero-Moss, International Commercial Arbitration: Different Forms and Their Features, Cambridge 2013, pp. 20-21.

15 D. Otto, O. Elwan, Article V(2), [in:] H. Kronke, P. Nacimiento, Recognition and Enforcement of Foreign Arbitral Awards: A Global Commentary on the New York Convention, the Netherlands 2010, p. 365.

16 Richardson v. Mellish, 2 Bing. 229 (1824) at 303.
} 
exhausted. In reality, it is frequently invoked as a basis for annulling arbitral awards ${ }^{17}$.

England became a signatory of New York Convention in 1975 and this had a profound effect on English arbitration law. The Arbitration Act 1975 implemented the New York Convention into English law and was later replaced by the Arbitration Act 1996 (1996 Act), which is currently the most updated arbitration statute in England. Part III of the 1996 Act gives effect to England's treaty obligations under the New York Convention. The 1996 Act contains a coherent framework for international and domestic arbitration and is influenced by the UNCITRAL Model Law on International Commercial Arbitration ${ }^{18}$. Under s66(1) of the 1996 Act the arbitral award may be enforced in the same way as a judgment or order of the court ${ }^{19}$. However, s68 allows the parties to challenge an arbitral award on the grounds of serious irregularity; and the award may be set aside in whole or in part ${ }^{20}$. S68(2)(g) lists "public policy" grounds as an example of a serious irregularity ${ }^{21}$. The court may also refuse to recognise or enforce an arbitral award under s103(1) \& (3) if such recognition or enforcement would be contrary to public policy ${ }^{22}$.

Arbitration can be an effective alternative dispute resolution if foreign arbitral awards are to be enforced abroad. Under the New York Convention the contracting states are obliged to enforce awards except in limited circumstances. This article will examine the extent to which the public policy exception under Article $\mathrm{V}(2)(b)$ of the New York Convention limits the enforcement of international arbitral awards in the $21^{\text {st }}$ century. Although it will mainly focus on England, it will also consider the position in European states such as Switzerland, Hungary, Austria, and Germany.

\footnotetext{
Born, supra note 5, p. 2621.

D. Sutton, J. Gill, M. Gearing, Russell on Arbitration, London 2007, pp. 20-22. NB: although the Arbitration Act 1996 was influenced by UNCITRAL Model Law, it differs from it in some aspects.

19 S661(1) Arbitration Act 1996.

$20 \quad$ S68 and s68(3) Arbitration Act 1996.

$21 \quad$ S68(2)(g) Arbitration Act 1996.

$22 \quad$ S103(1) \& (3) Arbitration Act 1996.
} 


\section{EARLY CASE LAW}

One of the early cases regarding public policy was David Taylor $\mathcal{E}$ Son v. Barnett Trading $\mathrm{Co}^{23}$ where the court refused to enforce an arbitral award on the grounds of illegality ${ }^{24}$. In this case, the defendants (D) agreed to sell to the plaintiffs $(\mathrm{P})$ Irish stewed steak at a price which exceeded the maximum price permitted by emergency legislation. When $\mathrm{D}$ failed to deliver the steak, $\mathrm{P}$ claimed damages. The dispute which arose was referred to arbitration. At first instance, D was ordered to pay damages to $\mathrm{P}$. The Court of Appeal held that the contract had been illegal and the arbitral award was set aside because "The court [had] jurisdiction to set aside an award based on an illegal contract, even where neither the umpire, nor even the parties knew that it was illegal" 25 . The David Taylor case ${ }^{26}$ proves that before England became a signatory of the New York Convention, judges were willing to refuse the enforcement of an arbitral award where the parties' contract was illegal and thus in conflict with the public policy of the state ${ }^{27}$.

The leading case which defined public policy in an enforcement proceeding under the New York Convention is Deutsche Schachtbau- und Tiefbohrgesellschaft $m b H \quad v$. Ras Al-Khaimah National Oil $\mathrm{Co}^{28}$. In this case the plaintiffs $(\mathrm{P})$ and the defendants (D) entered into an agreement for the exploration of oil. A dispute arose and $\mathrm{P}$ commenced arbitration proceedings. D responded by obtaining a judgment declaring the arbitration null and void ${ }^{29}$. $\mathrm{P}$ did not accept this and continued with the arbitration which resulted in an award in its favour registered in England; it was not recognised in Ras Al-Khaimah. Since P had no assets in England, the award could not be enforced. However, D later discovered

\footnotetext{
23 [1953] 1 W.L.R. 562.

24 The contract was illegal and this was contradictory to the fundamental principles of the judge's social system; therefore giving effect to the arbitral award would be contrary to public policy; http://agc-blog.agc.gov.my/agc-blog/?p=1398 (official portal of the Attorney General's Chambers of Malaysia) [last accessed: 17.07.2014].

25 Denning L.J. in David Taylor \& Son v. Barnett Trading Co. [1953] 1 W.L.R. 562 at 563.

$26 \quad$ David Taylor \& Son v. Barnett Trading Co. [1953] 1 W.L.R. 562.

27 Supra note 24.

28 [1987] 3 W.L.R. 1023; [1987] 2 Lloyd's Rep. 246.

29 This was not recognised in England.
} 
that an English company, Shell Co., had become indebted to $\mathrm{P}$ and obtained leave to enforce the arbitration award in England as a judgment ${ }^{30}$. $\mathrm{D}$ argued that it was contrary to public policy because the arbitrator applied unclear international rules, rather than applying the substantive law of a particular state ${ }^{31}$.

Sir John Donaldson M.R. disagreed with D and said that it was not contrary to public policy for the arbitrator to use principles underlying the law of the various nations governing contractual relations. He added that in order to refuse the enforcement of the award on the grounds of public policy there "has to be an element of illegality or that recognition or enforcement of the award would be clearly injurious to the public good, or, possibly, that recognition or enforcement would be wholly offensive to the ordinary reasonable and fully informed member of the public on whose behalf the powers of the State are exercised" 32 which D had failed to establish. Therefore if the enforcement of the award was not contrary to the "most basic" notions of morality and justice and was not clearly injurious to the public good which would outweigh the objectives of the New York Convention, public policy would not be considered as an obstacle to enforcement of the award ${ }^{33}$.

In Soleimany $v$. Soleimany ${ }^{34}$ the plaintiff $(\mathrm{P})$ exported Persian carpets from Iran in breach of Iranian law and the defendant (D) sold the carpets in England and elsewhere. P and D fell into dispute which they agreed to refer to the Beth Din, a rabbinical court of Judaism. The Beth Din made an award in favour of $\mathrm{P}$ on the basis that the parties were entitled to a share of the profits reflecting their contributions. P applied to register the award as a judgment. D resisted enforcement of the award on the grounds that illegality rendered the plaintiff's claim unenforceable in England and that it would be contrary to English public policy for an award founded on an illegal agreement to be enforced.

30 T. Hartley, International Commercial Litigation: Text, Cases and Materials on Private International Law, Cambridge 2009, pp. 767-769.

31 Deutsche Schachtbau- und Tiefbohrgesellschaft mbH v. Ras Al-Khaimah National Oil Co. [1987] 3 W.L.R. 1023 at 1023.

32 Sir John Donaldson M.R. Deutsche Schachtbau- und Tiefbohrgesellschaft mbH $v$. Ras Al-Khaimah National Oil Co. [1987] 3 W.L.R. 1023 at 1023 at 1035.

33 Paulsson, supra note 4, p. 217.

34 [1999] QB 785. 
The Court of Appeal refused to enforce an arbitration award on the grounds of public policy because the contract between the parties was illegal in nature. Waller LJ said that, "The court is (...) concerned to preserve the integrity of its process, and to see that it is not abused. The parties cannot override that concern by private agreement. They cannot by procuring arbitration (...) enforce an illegal contract. Public policy will not allow it $(\ldots)^{\prime \prime 35}$. The breach of public policy was apparent: the Beth Din had itself found that the contract was illegal under Iranian law ${ }^{36}$. The arbitral award was unenforceable because enforcing the award would tarnish the honour of the English judicial process ${ }^{37}$.

Waller LJ provided his (obiter) view as to what the reviewing court ought to do where an arbitral tribunal has not found that there was illegality ${ }^{38}$. He explained that if there is prima facie evidence of illegality, then the judge should conduct a preliminary inquiry to determine whether to give full faith and credit to the foreign arbitral award or else "to embark on a more elaborate inquiry into the issue of illegality" 39 . In his commentary, Grierson argued that the Court of Appeal had left open the difficult question of what such a preliminary inquiry should involve - should the court review the evidence that had been submitted to the arbitral tribunal, or should it merely conduct an audit of quality of the tribunal's review ${ }^{40}$ ?

Shortly after its decision in Soleimany ${ }^{41}$ the Court of Appeal revisited the same issue in Westacre Investments Inc. v. Jugoimport SDPR Holding Co. $L t d^{42}$. Academic comment on the Soleimany ${ }^{43}$ decision has been generally sympathetic between its pronouncement and the decision

\footnotetext{
35 Soleimany v. Soleimany [1999] QB 785 at 800.

36 J. Grierson, Mealey's International Arbitration Report: Court Review of Awards on Public Policy Grounds: A Recent Decision of the English Commercial Court Throws Light on the Position Under the English Arbitration Act 1996, International Arbitration Law Review 2009, vol. 24(1), p. 28. Note: under the applicable law, which was Jewish law, the fact that the contract was illegal under Iranian law had no effect on the enforceability of the contract.

37 http://agc-blog.agc.gov.my/agc-blog/?p=1398 [last accessed: 17.07.2014].

38 Grierson, supra note 36, p. 28.

39 Soleimany v. Soleimany [1999] QB 785 at 800.

40 Grierson, supra note 36, p. 28.

41 Soleimany v. Soleimany [1999] QB 785.

42 [2000] QB 288.

43 Soleimany v. Soleimany [1999] QB 785.
} 
in Westacre 44 owing to the extreme facts of the case; however, there was concern over the interventionist stance taken in it ${ }^{45}$. In Westacre ${ }^{46}$ the plaintiff $(\mathrm{P})$ entered into an agreement with the defendant (D) whereby $\mathrm{P}$ was appointed as a D's consultant for the sale of military equipment to Kuwait. A dispute arose and the arbitration tribunal issued an award in favour of $\mathrm{P}$ who obtained leave to enforce the award in England. $\mathrm{D}$ argued that the enforcement would be contrary to English public policy because $\mathrm{P}$ had bribed Kuwait government officials ${ }^{47}$. In this case, unlike in Soleimany ${ }^{48}$, the arbitral tribunal had made no finding of either corruption or influence peddling 49 .

The Court of Appeal was unanimous in holding that there was no reason to refuse the enforcement of the award and made no finding of either illegality or breach of public policy ${ }^{50}$. The Court of Appeal held that although the contract involved commercial corruption, the policy of giving effect to arbitral awards outweighed the policies against such conduct ${ }^{51}$. The majority agreed with the Colman J who held that "although commercial corruption is deserving of strong judicial and governmental disapproval, few would consider that it stood in the scale of opprobrium quite at the level of drug-trafficking" 52 . The majority strongly favoured the enforcement of foreign awards unless there was conclusive evidence (or at least a very strong suspicion) of serious illegality 53 .

\footnotetext{
$44 \quad$ Westacre Investments Inc. v. Jugoimport SDPR Holding Co. Ltd [2000] QB 288.

45 A. Johnson, Illegal Contracts and Arbitration Clauses, International Arbitration Law Review 1999, vol. 2, p. 35; C. Rose, The Strange Case of the Persian Carpet-Runner, Commercial Lawyer 1998, pp. 32-34; S. Wade, Westacre v. Soleimany: What Policy? Which Public?, International Arbitration Law Review 1999, p. 99.

$46 \quad$ Westacre Investments Inc. v. Jugoimport SDPR Holding Co. Ltd [2000] QB 288.

$47 \quad$ Ibidem, pp. 288-289.

48 Soleimany v. Soleimany [1999] QB 785.

49 Grierson, supra note 36, p. 28.

50 Ibidem.

51 Born, supra note 5, p. 2851.

52 Westacre Investments Inc. v. Jugoimport SDPR Holding Co. Ltd [1998] QB 740 at 773.

53 A. Sheppard, Case Comment: Whether Enforcement of a Foreign Award Should be Refused as Being Contrary to English Public Policy, on the Ground that the Underlying Agreement Concerned the Procurement of Personal Influence?, International Arbitration Law Review 1999, vol. 2(4), no. 47 , p. 47.
} 
As for the preliminary inquiry proposed by Waller LJ in Soleimany ${ }^{54}$, Mantell LJ held that, "For my part I have some difficulty with the concept and even greater concerns about its application in practice" 55 and Sir David Hirst agreed with him. He noted that in the present case the attempt to reopen the facts should be rebuffed because the arbitrators had specifically found that the underlying contract was not illegal56. Hence, where it is not possible to determine from the tribunal's reasoning that the award is contrary to public policy (e.g. tribunal held that the contract was not illegal in its place of performance), then the English courts will uphold the award, without conducting any kind of preliminary inquiry ${ }^{57}$.

It is argued that the decision in Westacre ${ }^{58}$ did little to develop the law ${ }^{59}$; in his article, Grierson emphasised that Westacre60 left many questions unanswered and the court had missed the chance to clarify the law in relation to "preliminary inquiry" 61. Although concise, some of the remarks made by the majority in the Court of Appeal shift the emphasis away from the decision in Soleimany62. In his article published in 1999, Wade concluded that the decision in Westacre ${ }^{63}$ and the rejection of Waller LJ's views on public policy "signifies a return to the emphasis normally placed on the continued unhindered operation of the New York Convention as an overriding policy in matters concerning international arbitration"64. However, there is a danger that when an international system develops rules of self-preservation that take precedent over the legitimate concerns of states this may, in the long run, become selfdefeating 65 .

The courts' approach towards the enforcement of foreign arbitral awards was not clear and often contradictory prior to 2000. Even after

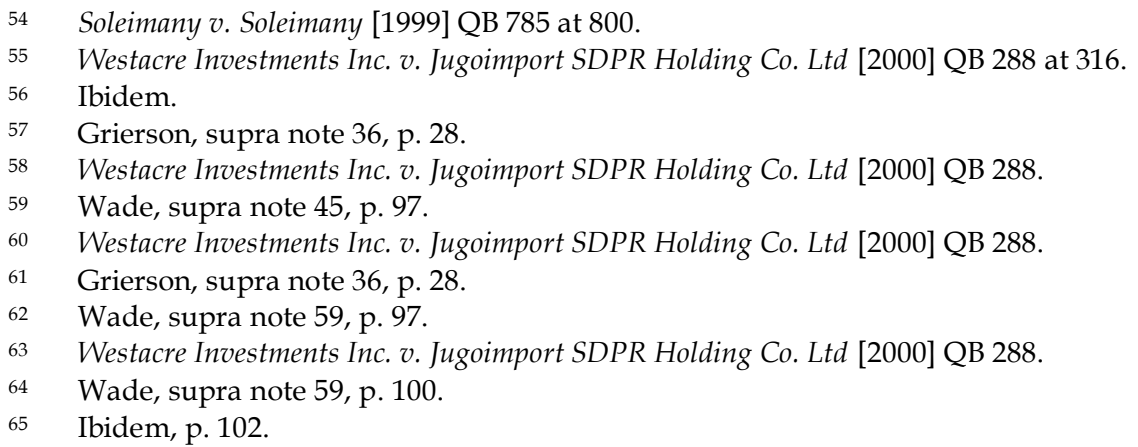


England became a signatory to the New York Convention, there was no consistency in the courts' rulings; in some cases (e.g. Soleimany ${ }^{66}$ ) the court was prepared to prevent the enforcement of the award on a public policy ground while in others, for instance in Westacre ${ }^{67}$, it was not. Furthermore since the law offered little certainty on the issue of "preliminary inquiry", there was a chance that the court would be allowed to review a decision of the arbitral tribunal on the law or on the merits, in which case the speed and, above all, the finality of the arbitral process would be lost ${ }^{68}$.

\section{DEVELOPMENTS POST-WESTACRE}

\section{NOT ENABLED TO HAVE THEIR CROSS-CLAIM TAKEN INTO ACCOUNT}

In Tongyuan (USA) International Trading Group v. Uni-Clan Limited 69 a contract was made for the sale of two sachet-filling machines. Both machines were sold in the People's Republic of China. There was no express choice of law in the contract, but the arbitrators found that it was governed by Chinese law. The buyers $(\mathrm{P})$ alleged that the machine was defective and referred the matter to arbitration. The sellers (D) took no part in the proceedings. The tribunal ordered the arbitral award. Mr Aylwin (instructed by D) submitted that it would be contrary to public policy under s103 of the Arbitration Act 1996 for the court to allow the award to be enforced in a manner which did not enable $\mathrm{D}$ to have their cross-claim taken into account ${ }^{70}$.

Mr Justice Moore-Bick held that there was a very strong public policy consideration in favour of enforcing awards and "it would require a very strong and unusual case to render the enforcement of an award in circumstances of this kind contrary to public policy"71. He noted that he had seen nothing in the evidence which would lead him to such

\footnotetext{
66 Soleimany v. Soleimany [1999] QB 785 at 800.

67 Westacre Investments Inc. v. Jugoimport SDPR Holding Co. Ltd [2000] QB 288.

68 A. Redfern, M. Hunter, Law and Practice of International Commercial Arbitration, London 2004, p. 412.

69 [2001] WL 98036.

70 Tongyuan (USA) International Trading Group v. Uni-Clan Limited [2001] WL 98036 at 12.

71 Ibidem, p. 14.
} 
conclusion; hence, D's application was unsuccessful. Mr Justice Moore-Bick reached similar conclusions to Waller LJ in Westacre ${ }^{72}$ who found that the policy of giving effect to arbitral awards outweighed the policies against $\mathrm{P}^{\prime} \mathrm{s}$ conduct.

\section{ENFORCEMENT WOULD VIOLATE THE LAW OF THE FOREIGN COUNTRY}

In Tamil Nadu Electricity Board v. ST-CMS Electric Co. Private Ltd73, the agreement between the claimant (C) and defendant (D) was governed by the law of India and was for the supply of energy and capacity from an electricity plant. The agreement provided for the settling of disputes by arbitration according to the laws of England. D applied to ICC $^{74}$ and claimed that $C$ had used an incorrect computation methodology for the calculation of the tariff payable by $C$ to D. C then applied to the court under s72 of the Arbitration Act 1996 seeking a declaration that the matters submitted by $\mathrm{D}$ to arbitration were not within the scope of the arbitration agreement and an injunction restraining D from continuing the arbitration. C submitted that the court should not enforce the arbitration agreement because effect should be given to Indian substantive law and questions of English public policy were involved ${ }^{75}$.

The applications were refused. The Honourable Mr Justice Cooke held that the parties' clear intention was that English law should prevail over Indian law in determining the scope of the arbitration agreement, since the arbitration clause was separable from the rest of the contract ${ }^{76}$. He noted that it was not enough that the contract was contrary to public policy according to the law of the foreign country in which it happened to be made and explained that, for the contract to be contrary to English public policy, "[it] must be unlawful by the law of the country in which, according to its express or implied terms, [it] has to be performed"77. In this case,

\footnotetext{
72 Westacre Investments Inc. v. Jugoimport SDPR Holding Co. Ltd [1999] 2 Lloyd's Rep. 65 at 80; the comment made by G.B. Born in: Born, supra note 5, p. 2851.

73 [2007] EWHC 1713 (Comm).

74 International Chamber of Commerce.

75 Tamil Nadu Electricity Board v. ST-CMS Electric Co. Private Ltd [2007] EWHC 1713 (Comm).

$76 \quad$ Ibidem, p. 32.

$77 \quad$ Ibidem, p. 47.
} 
it was not necessary that performance took place in India itself 78 ; hence, there was no public policy consideration relating to illegal performance of the contract which would compel an English court to refrain from enforcing the arbitral clause ${ }^{79}$.

In Tamil Nadu Electricity Board 80 the court found that for the contract to be contrary to public policy it must be unlawful in the country where it has to be performed according to its express or implied terms; therefore the court once again was reluctant to limit the enforcement of the international arbitral award on public policy grounds. In his article Gerhardt Will said that, "it would be entirely artificial if (...) a court intervened in the face of clear evidence as to the autonomous intention of the parties, and refused to enforce the arbitral agreement. By refraining from such intervention, the English court has set arbitration clauses on a firm footing, grounded on liberally-construed international policy grounds"81; thus, he praised the judge for non-interventionist stance.

\section{CONTRARY TO NATURAL JUSTICE}

English public policy may be violated if an award was obtained contrary to the rules of natural justice ${ }^{82}$. In Gater Assets Ltd v. Nak Naftogaz Ukrainiy $^{83}$ the defendant (D) applied to set aside an order permitting the claimant $(\mathrm{C})$ to enforce an arbitral award as a judgment. D distributed gas supplied by Gazprom, which paid for transit of gas through Ukraine by permitting $\mathrm{D}$ to withdraw a certain amount of gas from the pipeline. In 1999 Gazprom alleged that D had taken a greater quantity of gas than it was entitled to under the contract. As a result, Gazprom and its captive insurer (Sogaz) entered into a reinsurance contract, which was not

\footnotetext{
78 G. Will, Case Comment: Jurisdiction and Public Policy in the Case of Tamlin Nadu Electricity Board v. ST-CMS Electric Co. Private Ltd: a Policy of Caution is the Greatest Risk, International Arbitration Law Review 2007, vol. 10(6), p. 66.

79 Ibidem, p. 68.

80 Tamil Nadu Electricity Board v. ST-CMS Electric Co. Private Ltd [2007] EWHC 1713 (Comm)

81 Will, supra note 78, p. 69.

82 G. Maurer, The Public Policy Exception under the New York Convention, JurisNet 2013, LLC, p. 92.

83 [2008] EWHC 237 (Comm).
} 
disclosed to ICAC ${ }^{84}$, with the intention of vesting in a subrogated nonRussian reinsurer (M) the right to pursue Gazprom's claim against D. The ICAC issued an award in favour of M. In 2006, M assigned to the claimant $\mathrm{C}$ the benefit of the ICAC award. D argued that enforcing the award in England would be contrary to public policy because it had been procured by dishonest means.

The Hon. Mr Justice Tomlinson agreed with Moore-Bick J.85 that where a party who deliberately withheld an important document obtains an award in his favour, the court could consider that the award was procured in a manner contrary to public policy. However, he noted that innocent failure to disclose a document, even an important one, could not properly be described as acting contrary to public policy ${ }^{86}$. He held that, "what would normally be required to be demonstrated, for the court to conclude that an award has been procured by a party in a way which is contrary to public policy, will be some form of reprehensible or unconscionable conduct (...). That means conduct which we would be comfortable in describing as fraud, conduct dishonestly intended to mislead" 87 . Since D failed to prove that $\mathrm{M}$ had engaged in "reprehensible or unconscionable" conduct in an attempt to mislead the arbitral tribunal, the court could not set aside the order permitting enforcement of the award.

Although the court defined a situation in which enforcement of the arbitral award would be contrary to public policy, it was unwilling to refuse the enforcement of it in this case. Therefore, if someone decided to challenge the enforcement of a foreign arbitral award in a similar case, he would need to prove that the other party deliberately failed to disclose an important document; proving innocent failure would not suffice. In both Westacre 88 and in Gater Assets ${ }^{89}$ the court held that fraud would be contrary to public policy. The only difference was that in the former case, Colman J

\footnotetext{
84 International Commercial Arbitration Court in Moscow.

85 Moore-Bick J in Profilati Italia Srl v. Painewebber Inc. [2001] 1 All E.R. (Comm) 1065 at 19.

86 The Hon. Mr Justice Tomlinson Gater Assets Ltd v. Nak Naftogaz Ukrainiy [2008] EWHC 237 (Comm) at 40.

87 The Hon. Mr Justice Tomlinson Gater Assets Ltd v. Nak Naftogaz Ukrainiy [2008] EWHC 237 (Comm) at 40-41.

$88 \quad$ Westacre Investments Inc. v. Jugoimport SDPR Holding Co. Ltd [1998] QB 740 at 775.

89 Gater Assets Ltd v. Nak Naftogaz Ukrainiy [2008] EWHC 237 (Comm) at 40.
} 
called it a "universally condemned activity" while in the latter, Tomlinson J described it as a "reprehensible or unconscionable conduct".

\section{CORRUPT PRACTICES}

In $R v . V^{90}$ the claimant (C) entered into a consultancy agreement with the defendant (D) whereby D promised to assist and advise C's subsidiary in its negotiations with the Libyan national oil company with the purpose of obtaining approval of certain development plans. In spite of the fact that $\mathrm{C}$ made payments specified in the agreement following the approval of the development plans, D claimed further payments for "strategic assistance". $D$ referred the matter to arbitration. The tribunal ruled in favour of D and ordered $\mathrm{C}$ to pay the remaining fee. $\mathrm{C}$ challenged the arbitration award and claimed that the agreement was illegal under Libyan law and contrary to English public policy pursuant to s68(2)(g) of the Arbitration Act 1996 in regard to influence peddling. The fact situation in $R v$. $V^{91}$ was closer to that in Westacre ${ }^{92}$ than that in Soleimany ${ }^{93}$ : the arbitrators decided that the agreement was contrary to neither the lex loci solutionis ${ }^{94}$ nor English public policy and the parties had fully debated the illegality/public policy issue ${ }^{95}$.

David Steel J held that he would "accord the award full faith and credit, even if it were appropriate to embark on any form of preliminary inquiry"96 and noted that he was bound by the decision in Westacre ${ }^{97}$. He reiterated the concerns expressed by the majority in Westacre ${ }^{98}$ about the application of the "preliminary inquiry". Although he held that an inquiry into the alleged breach of public policy was not permissible,

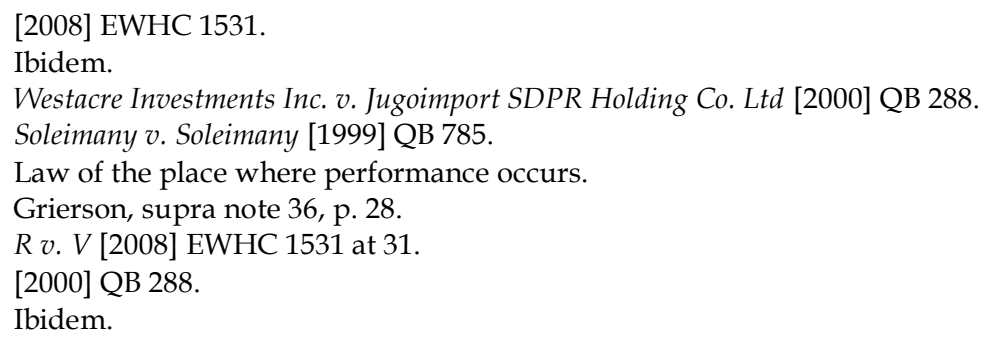


he went on to review the merits and indicated that on the facts such allegations were not sustainable ${ }^{99}$.

Even though the preliminary enquiry 100 in $R v \cdot V^{101}$ was relatively simple, it required a one-and-a-half-day hearing and substantial legal fees. In other cases, the preliminary enquiry could be considerably more difficult to perform ${ }^{102}$. If someone decided to pursue a case for the enforcement of the foreign arbitral award in England, he should bear in mind the commercial risks involved stemming from the court's ability to reopen the arbitral tribunal findings. The legitimacy and proper scope of such an inquiry remain unclear ${ }^{103}$.

David Steel J held that in order for the contracts for the purchase of personal influence not to be enforced in England, their performance would need to be contrary to the domestic public policy of the country of performance (Westacre ${ }^{104}$ applied) ${ }^{105}$; and that the tribunal's conclusion that the agreement was not illegal as a matter of Libyan law was unimpeachable ${ }^{106}$. He agreed with the majority in Westacre107 and Colman J108, who accorded "an appropriate level of opprobrium" at which to place commercial corruption - "although commercial corruption is deserving of strong judicial and governmental disapproval, few would consider that it stood in the scale of opprobrium quite at the level of drug trafficking"109. In Westacre110, the Court of Appeal concluded that acts such as terrorism and drug trafficking would infringe public policy which

\footnotetext{
$99 \quad R$ v. V [2008] EWHC 1531 at 49; Public Policy and Enforcement of Awards, available online: http:/ / uk.practicallaw.com.lawdbs.lawcol.com/2-382-6040?q=\%5B2008\%5D+EWHC+1531 [last accessed: 1.08.2014].

100 As already explained above, an inquiry into the alleged breach of public policy was not permissible; nonetheless, David Steel J went on to review the merits. "He found that the tribunal's conclusion that the [consultant] agreement was not illegal as a matter of [the lexi loci solutionis was] unimpeachable" - Grierson, supra note 36, p. 3.

$101 \quad R v . V$ [2008] EWHC 1531.

102 Grierson, supra note 36, p. 28.

103 Public Policy and Enforcement of Awards, supra note 99.

104 Westacre Investments Inc. v. Jugoimport SDPR Holding Co. Ltd [2000] QB 288.

105 R v. V [2008] EWHC 1531 at 27.

$106 \quad R v . V$ [2008] EWHC 1531 at 43.

107 Westacre Investments Inc. v. Jugoimport SDPR Holding Co. Ltd [2000] QB 288.

108 Colman J in Westacre Investments Inc. v. Jugoimport SDPR Holding Co. Ltd [1999] QB 740 at 773 .

$109 \quad$ R v. V [2008] EWHC 1531 at 32.

110 Westacre Investments Inc. v. Jugoimport SDPR Holding Co. Ltd [2000] QB 288.
} 
would lead to non-enforcement of an arbitral award; nonetheless, commercial corruption would not. In $R v \cdot V^{111}$ the court was once again unwilling to refuse the enforcement of the foreign arbitral award on public policy grounds.

\section{MONEY LAUNDERING}

In Nomihold Securities Inc. v. Mobile Telesystems Finance SA112, the claimant (C) had sold the defendant (D) a majority shareholding in a company $(\mathrm{T})$, registered in The Seychelles, under a share purchase agreement. Under that agreement $\mathrm{C}$ exercised its entitlement to sell the remaining shares to $\mathrm{D}$ under a put option. Clause 4 of the $\mathrm{POA}^{113}$ provided that $\mathrm{T}$ would pass the necessary resolutions to register the new ownership of its shares in the name of $\mathrm{D}$. A dispute arose as $\mathrm{D}$ discovered that $\mathrm{T}$ did not indirectly own shares in the Kyrghyz company (B). Accordingly, the issues at arbitration were geared towards D extricating itself from its obligation to purchase the remaining shares under the put option on the basis that $\mathrm{T}$ no longer indirectly owned the shares in $\mathrm{B}$.

The arbitrators found that $C$ had been entitled to sell the shares to $D$, so that the agreed purchase price had become due. Moreover, $\mathrm{T}$ commenced proceedings in the Seychelles seeking directions as to whether it could register the transfer of its shares in D's name as it was concerned that such a transfer could constitute a breach of Seychellois money laundering provisions. D claimed, among other things, that allegations of money laundering in the Seychelles meant that the award ought not to be enforced in England on public policy grounds.

Burton J held that the alleged money laundering had not "contributed in a substantial way" to $\mathrm{C}$ obtaining an award in its favour relating to the breach of contract by D. "The fact that [T], which [D] controls, has not registered the transfer of ownership from [C] to [D] does not (...) amount

\footnotetext{
111 R v. V [2008] EWHC 1531.

112 [2011] EWHC 2143.

113 Put Option Agreement. The arbitration related to whether C, having previously sold to D 51 per cent of the shares of T by a Share Purchase Agreement dated 17.11.2005, to which no challenge was made, was entitled to exercise its put option to sell to $\mathrm{D}$ the balance of 49 per cent of shares in T under the POA, by an exercise of its put option on 18.11.2006.
} 
to a reason why the English courts should not enforce the Award"114. He noted that $\mathrm{D}$ had had over five months before the commencement of the proceedings to articulate a case that there was any relevance to the alleged money laundering which could prevent enforcement of the award; nonetheless, D had not done so ${ }^{115}$. The application was refused.

Therefore, in order for such claim to be successful, the alleged money laundering must contribute in a "substantial way" to the other party obtaining an award in its favour.

When advising clients on issues similar to the ones considered in the aforementioned cases, the practitioner should bear in mind the following points. First, it is unlikely that the court will refuse the enforcement of the award on public policy grounds if the client argues that he was not able to have his cross-claim taken into account ${ }^{116}$. Second, for the contract to be contrary to English public policy, the contract must be unlawful by the law of the country in which, according to express or implied terms, it has to be performed. It is not enough that the contract is contrary to public policy according to the law of the foreign country in which it happens to be done ${ }^{117}$.

Third, where a party who deliberately withheld an important document obtains an award in its favour, the court could consider that award was procured in a manner contrary to public policy; nonetheless, innocent failure to disclose a document would not be sufficient ${ }^{118}$. Fourth, commercial corruption does not infringe public policy ${ }^{119}$.

Fifth, there is a risk that the court will decide that it is appropriate to embark on some form of preliminary inquiry to determine whether to give full faith and credit to the foreign arbitral award and this may lead to higher legal costs120; thus the law on "preliminary inquiry" remains uncertain. Sixth, in order for the award not to be enforced in England

\footnotetext{
114 Burton J in Nomihold Securities Inv v. Mobile Telesystems Finance SA [2011] EWHC 2143 at 64 .

115 Ibidem, p. 64.

116 Tongyuan (USA) International Trading Group v. Uni-Clan Limited [2001] WL 98036 at 14.

117 Tamil Nadu Electricity Board v. ST-CMS Electric Co. Private Ltd [2007] EWHC 1713 at 47.

118 Gater Assets Ltd v. Nak Naftogaz Ukrainiy [2008] EWHC 2372 at 40.

119 R v. V [2008] EWHC 1531 at 32.

120 Ibidem, p. 31.
} 
because of money laundering, the alleged money laundering would need to contribute substantially to the other party obtaining an award in its favour. Also, the case should be brought to the court's attention as soon as possible as any delay may negatively affect the client's chances of being successful ${ }^{121}$.

In the $21^{\text {st }}$ century, the courts in England and Wales are more reluctant to refuse the enforcement of the foreign arbitral awards on the grounds of public policy. It can be argued that since Westacre122, the law surrounding the public policy exception has become more predictable because the "pro enforcement bias" of the New York Convention has been more faithfully observed. Even though in both Westacre ${ }^{123}$ and $R \quad v$. V124 the concept of "preliminary inquiry" introduced by Waller LJ was addressed, the legitimacy and proper scope of such an inquiry remain unclear ${ }^{125}$.

\section{PUBLIC POLICY IN EUROPE}

While English courts are unwilling to refuse the enforcement of foreign arbitral awards under s68(2)(g) or s103(3) or the Arbitration Act 1996 in $21^{\text {st }}$ century, some developed courts in Europe have set aside arbitral awards on the basis of violation of public policy.

\section{SWITZERLAND}

Switzerland became a signatory of the New York Convention on 29 December 1958 and ratified it on 1 June 1965; it became effective in Switzerland on 30 August 1965126. Article 194 of the Swiss Private International Law Act states that, "The recognition and enforcement of a foreign arbitral award is governed by the New York Convention

\footnotetext{
121 Nomihold Securities Inc. v. Mobile Telesystems Finance SA [2011] EWHC 2143 at 64.

122 Westacre Investments Inc. v. Jugoimport SDPR Holding Co. Ltd [2000] QB 288.

123 Ibidem.

$124 \quad R v . V$ [2008] EWHC 1531.

125 Public Policy and Enforcement of Awards, supra note 99.

126 UNCITRAL. Status: 1958-Convention on the Recognition and Enforcement of Foreign Arbitral Awards - http://www.uncitral.org/uncitral/en/uncitral_texts/arbitration/ NYConvention_status.html [last accessed: 8.08.2016].
} 
of 10 June $1958(\ldots)^{\prime \prime 127}$. In Switzerland, there is no implementing legislation for the enforcement of the New York Convention. The Convention is applied as a self-executing treaty and its provisions take precedence over any federal or cantonal rules of law on the recognition and enforcement of foreign arbitral awards ${ }^{128}$. Under Article 190(2)(e) of the Swiss Private International Law Act (PILA) an arbitral award may be set aside if it is incompatible with public policy.

For the first time, the Swiss Federal Tribunal set aside an arbitral award on the basis of violation of public policy in Club Atletico de Madrid $S A D$ v. Sport Lisboa E Benfica - Futebol $S A D^{129}$. In this case the underlying dispute arose between Sport Lisboa (B) and Atletico de Madrid (A) when a soccer player terminated his employment contract with $\mathrm{B}$ and transferred to A. In 2001, B claimed compensation from FIFA. In 2002, FIFA awarded B $\$ 2,5 \mathrm{~m}$ and A appealed to the Commercial Court. In 2004, the Commercial Court annulled the decision. A few months later B again claimed compensation, but FIFA rejected the claim relying on 2004 judgment. $\mathrm{B}$ appealed against the second FIFA decision to the Court of Arbitration for Sports (CAS). CAS ordered A to pay compensation in the amount of EUR 400,000. A filed a petition with the Swiss Federal Tribunal and claimed that CAS violated procedural public policy as it disregarded the binding effect of the 2004 judgment ${ }^{130}$.

In 2010, the Swiss Federal Tribunal ${ }^{131}$ held that the Commercial Court's decision annulling a resolution of FIFA bound not only FIFA and A (parties to the proceedings), but also B. For that reason, B's claim before CAS was barred by res judicata ${ }^{132}$ even though B was not a party to the 2004

\footnotetext{
127 A. van den Berg, Yearbook: Commercial Arbitration, vol. XXVIII, the Netherlands 2003, p. 837 , fn 1 .

128 Maurer, supra note 82, p. 176.

129 Judgment of 13.04.2010; case no. 4A_490/2009.

130 N. Voser, J. Menz, S. Wittmer, Swiss Federal Tribunal Sets Aside CAS Award for Violation of Procedural Public Policy, 2010, available online: http://uk.practicallaw.com/5-5029576? source=relatedcontent [last accessed: 20.08.2014].

131 The Swiss Federal Tribunal, which is the Supreme Court in Switzerland, acts as an appellate court, reviewing cases decided by lower federal courts and cantonal (state) courts.

132 Res judicata - this doctrine prevents a party from re-litigating any claim or defence already litigated, or that could have been litigated, previously. The doctrine is meant
} 
judgment. Federal Tribunal confirmed that res judicata is a part of Swiss procedural public policy, which CAS violated by granting B's claim despite the 2004 judgment ${ }^{133}$. The court noted that "disregard of [fundamental and generally recognised procedural principles] contradicts the sense of justice in an intolerable way, so that the decision appears absolutely incompatible with the values and legal order of a state ruled by laws" 134 .

In their article published in 2010, Berger \& Sun argued that since it was the first decision by the Swiss Federal Tribunal to overturn an arbitration award based on public policy, it is unclear how the decision would be construed or applied by other courts in the future ${ }^{135}$. Voser \& Menz \& Wittmer mentioned that Club Atletico de Madrid136 was a landmark decision which would undoubtedly spawn much commentary in the Swiss and international arbitration communities ${ }^{137}$.

It was not long after Club Atletico de Madrid138 that the Swiss Federal Tribunal, once again, decided to refuse the enforcement of a foreign arbitral award on public policy grounds. In Francelino da Silva Matuzalem v. FIFA139, Matuzalem (M) terminated his contract with the Shaktar Donetsk (S) ${ }^{140}$ to play for the Spanish club Real Zaragoza (R). CAS141 ordered that M and $\mathrm{R}$ were jointly and severally liable to pay to Shaktar Donetsk damages of nearly EUR $12 \mathrm{~m}$. Setting aside proceedings were brought against that award, but the Federal Tribunal dismissed the application and upheld the award in 2010. As M and R were unable to pay the damages awarded,

to ensure the finality of judgments and conserve judicial resources by protecting litigants from multiple litigation involving the same claims or issues.

133 Facts of the case found in J. Berger, C. Sun, Paul Hastings: Stay Current - A Client Alert From Paul Hastings, 2010, available online: https://www.paulhastings.com/docs/ default-source/PDFs/1712.pdf [last accessed: 8.08.2016]; and in Voser, Menz, Wittmer, supra note 130 .

134 Translated judgment availabel online: http://www.swissarbitrationdecisions.com/ sites/default/files/13 avril 2010 4A 490 2009.pdf [last accessed: 8.08.2016]. Quote found at para 2.1.

135 Berger, Sun, supra note 133.

136 Judgment of 13.04.2010 in case no. 4A_490/2009, Club Atletico de Madrid SAD v. Sport Lisboa E Benfica - Futebol SAD.

137 Voser, Menz, Wittmer, supra note 130.

138 Judgment of 13.04.2010 in case no. 4A_490/2009, Club Atletico de Madrid SAD v. Sport Lisboa E Benfica - Futebol SAD.

139 Judgment of 27.03.2012 in case no. 4A_558/2011.

140 Ukrainian football club.

141 Court of Arbitration for Sports. 
the FIFA Disciplinary Committee threatened to ban $\mathrm{M}$ from any football related activity until he paid the entire amount. On appeal, the decision of FIFA was confirmed by CAS in 2011. M sought to have this new CAS award set aside. $M$ argued that the award, and more specifically the underlying sanction of a potential playing ban, violated public policy within the meaning of Article 190(2)(e) of the PILA ${ }^{142}$.

The Federal Tribunal held that the sanction was not necessary since the CAS award ordering $M$ to pay damages could be enforced under the New York Convention on the Recognition and Enforcement of Arbitral Awards of 1958. The threat of a ban from future football activities constituted a serious interference with the player's personal rights. The abstract objective of enforcing compliance by football players with the duties owed to their employees is insufficient to let the scales come down in favour of a worldwide professional ban on the player. The Federal Tribunal found that the CAS award was contrary to substantive public policy and it was set aside ${ }^{143}$.

Lenz \& Staehelin said in their article that this judgment was of "paramount importance"144, while Voser \& George \& Wittmer noted that this decision was to be welcomed, coming at a time when there was an increasing call for checks and balances in sports arbitration ${ }^{145}$. In this case, the Swiss Federal Tribunal considered the personality rights of the player more important than the principle of keeping the agreement he entered into (i.e. FIFA Disciplinary Code to which he agreed). The Matuzalem $v$. FIFA ${ }^{146}$ case showed that the enormous compensation

142 Facts of the case found in N. Voser, A. George, S. Wittmer, Landmark Ruling of Swiss Supreme Court Setting Aside CAS Award for Violation of Substantive Public Policy, 2012, available online: http://uk.practicallaw.com/1-519-2649?q=public+policy+switzerland [last accessed: 21.08.2014]; Lenz, Staehelin, Newsflash May 2012: CAS Award Set Aside for Breach of Substantive Public Policy, 2012, available online: http://www.lenzstaehelin.com/uploads/tx_netvlsldb/ Newsflash_May_2012.pdf [last accessed: 8.08.16].

143 Lenz, Staehelin, supra note 142.

144 Ibidem.

145 Voser, George, Wittmer, supra note 142.

146 Judgment of 27.03.2012 in case no. 4A_558/2011, Francelino da Silva Matuzalem v. FIFA. 
which CAS used to order soccer players to pay to their former clubs for terminating their contracts without just cause, may be difficult to enforce ${ }^{147}$.

"Public policy" remains very narrowly defined by the Swiss Federal Tribunal148, however these two recent judgments can be seen as an illustration of the more lenient approach adopted by Swiss courts towards the public policy exception in sports cases.

\section{HUNGARY}

Hungary acceded to the New York Convention on 5 March 1962 and the Convention became effective in Hungary on 3 June 1962. The New York Convention was implemented to Hungarian law by Law Decree 25 of 1962. In 2003, the Hungarian Supreme Court refused to enforce an arbitral award based on the public policy exception in BH 2003, 127 (case reference number). The arbitral tribunal decided a dispute for the value of 32 billion Forint and awarded to the claimant lawyers' fees in the amount of 290 million Forint for the proceedings which lasted 16 months. The plaintiff in the Hungarian proceedings argued that such fees not only punished the losing party disproportionately, but also harmed the sense of value of society and thereby was contrary to public policy ${ }^{149}$. The Hungarian Supreme Court held that no breach of regulation is necessary to determine that an arbitral award is contrary to public policy.

The Supreme Court reasoned that, "the 290 million Forint lawyers' fee is considered a disproportionately high sum. For such an award to remain effective, it would have an unwanted negative effect on the Hungarian legal practice that is a part of the legal order. Therefore, it is contrary to public policy"150. Hence, the Supreme Court agreed with the plaintiff and confirmed that such high legal fees would harm the sense of value of society ${ }^{151}$.

\footnotetext{
147 R. Levy, Swiss Federal Tribunal Overrules CAS Award in a Landmark Decision, 2012, available online: http://www.lawinsport.com/articles/regulation-a-governance/item/ swiss-federal-tribunal-overrules-cas-award-in-a-landmark-decision [last accessed: 8.08.2016].

148 Lenz \& Staehelin, supra note 142.

149 BH 2003, 127 et seq. at 4.

150 BH 2003, 127 et seq. at 11.

151 Maurer, supra note 82, p. 122.
} 


\section{AUSTRIA}

The New York Convention became effective in Austria on 31 July 1961 and it is directly applicable based upon the $\S 86(1)$ Execution Ordnance. In Austria, the Supreme Court also set aside an award on public policy grounds in 2005. In 30b221/04b (case reference number) the parties concluded a contract under which the Yugoslav seller (S) undertook to supply mushrooms to the Austrian buyer (B). A dispute arose between the parties when B did not pay part of the sale price for a delivery of mushrooms. S commenced arbitration and the tribunal rendered an award in favour of $S$ directing $B$ to pay 22,500 DM to $S$ and to pay contractually agreed interest for late payment of 0.2 per cent per day with daily capitalisation on a purchase price due in Deutsche Marks which amounted to an effective annual interest rate of 107.35 per cent. $S$ sought enforcement of the award in Austria; B claimed that the award violated public policy because the rate of interest was excessive ${ }^{152}$.

The Supreme Court held that "the relevant standard for an autonomous public policy review of the foreign arbitral award (...) is whether the arbitral award is irreconcilable with the fundamental principles of the Austrian legal system because it is based on a foreign legal principle that is totally irreconcilable with the domestic legal system" 153 . It reasoned that the interest rate of 107.35 per cent constitutes an excessive abuse of private autonomy and as such is not only immoral and void under Article 879(1) Austrian Civil Code, but is also contrary to Austrian public policy because interest aims at protecting monetary value and cannot have a punitive function 154 .

Although the law at the place of performance (Yugoslavia) allowed such high interest payments owing to the exorbitant inflation rate of the local currency, such a rate would have been illegal if applied to a "hard" currency ${ }^{155}$. Therefore, the Supreme Court refused to enforce the arbitral

\footnotetext{
152 A. van den Berg, Yearbook: Commercial Arbitration, vol. XXX, the Netherlands 2006, pp. 421-422.

153 Ibidem, p. 428; Maurer, supra note 82, p. 76.

154 Maurer, supra note 82, p. 76.

155 H. Kronke, P. Nacimiento, D. Otto, N.C. Port, Recognition and Enforcement of Foreign Arbitral Awards: Global Commentary on The New York Convention, the Netherlands 2010, p. 392.
} 
award because the agreed interest rate was irreconcilable with the fundamental principles of the Austrian legal system ${ }^{156}$.

\section{GERMANY}

The New York Convention became effective in Germany on 28 September 1961. Section 1061(1) of the German Code of Civil Procedure stipulates that, "Recognition and enforcement of foreign arbitral awards shall be granted in accordance with the [New York] Convention of June 10, $1958(\ldots)^{\prime 157}$. In Germany, the Court of Appeals is competent for decisions on application relating to a declaration of the enforceability of an award ${ }^{158}$.

In $4 \mathrm{Z}$ Sch 17/03 (case reference number) the parties concluded a supply contract which contained an arbitration clause. The claimant (C) commenced arbitration and at the arbitral tribunal's suggestion, the parties entered into settlement negotiations and agreed that $C$ would withdraw proceedings if the defendant (D) paid the amounts in dispute. D duly paid the amounts, but $\mathrm{C}$ did not terminate the proceedings and obtained a favourable award. $C$ then sought enforcement in Germany ${ }^{159}$.

The Higher Court of Appeals of Bavaria 160 denied enforcement of an award made in Russia on the grounds of public policy because the award had been made after the parties had reached a settlement which had been concealed from the arbitrators 161 . It held that the award "deviates to a large extent from the norms and legal principles that are the foundation of the German legal system (...) the principle of contractual good faith would be violated in a manner that is irreconcilable with the [German] legal system if [C] obtained enforcement" 162 .

\footnotetext{
156 Maurer, supra note 82, pp. 75-76.

157 Ibidem, p. 104.

158 Ibidem.

159 Facts of the case available in: New York Convention Guide, available online: http:/ / newyorkconvention1958.org/index.php?lvl=notice_display\&id=271 [last accessed: 8.08.2016].

160 Bayerishes Oberstes Landesgericht - Higher Court of Appeals of Bavaria, often called Bavarian Supreme Court.

161 Maurer, supra note 82, p. 111.

162 Ibidem, referring to A. van den Berg, Yearbook: Commercial Arbitration, vol. XXXII, the Netherlands 2004, para 6, p. 773.
} 
The violation in this case went beyond a mere procedural defect ${ }^{163}$. The Higher Court of Appeals of Bavaria refused to enforce the award because it was irreconcilable with fundamental principles of the German legal system; thus, the award was set aside for the same reasons as in the Austrian case number: 3Ob221/04b (above).

\section{CONCLUSION}

Even though the English courts attempted to define situations in which arbitral awards would be contrary to public policy, they are reluctant to refuse enforcement of the awards on that ground in the $21^{\text {st }}$ century; they "[continue] unhindered operation of the New York Convention as an overriding policy in matters concerning international arbitration" 164 . Nonetheless, this is not the case in every European state. As seen from the aforementioned cases, some developed courts in Europe take a more interventionist stance than the English courts.

The Austrian Supreme Court in 3Ob221/04b and the German Higher Court of Appeals of Bavaria in 4 Z Sch 17/03 both set aside an arbitral award on the grounds of public policy because the awards were irreconcilable with fundamental principles of their legal systems. In the former case, the contractually agreed interest rate was excessive and thus illegal; while in the latter case, the arbitral award could not be enforced because it had been made after the parties had reached a settlement which had been concealed from the arbitrators.

In Hungary, the Supreme Court concluded that an arbitral award was contrary to public policy because the disproportionately high legal fees awarded to the claimant would harm the sense of value of society ${ }^{165}$. In Switzerland, the two recent judgments of the Swiss Federal Tribunal can be seen as an illustration of the more lenient approach adopted by Swiss

\footnotetext{
163 New York Convention Guide, available online: http://newyorkconvention1958.org/ index.php?lvl=notice_display\&id=271 [last accessed: 8.08.2016].

164 Wade, supra note 45 , p. 100

165 BH 2003, 127.
} 
courts towards Article V(2)(b) of the New York Convention, in sports cases $^{166}$.

Hence, when advising a client who wishes to enforce a foreign arbitral award in a European state other than England, a practitioner should inform him that his chances of successfully enforcing a foreign arbitral award may be significantly lower than in England, the litigation may last longer, and as a consequence the client may incur much higher legal costs.

166 Judgment of 27.03.2012 in case no. 4A_558/2011, Francelino da Silva Matuzalem v. FIFA; judgment of 13.04.2010 in case no. 4A_490/2009, Club Atletico de Madrid SAD v. Sport Lisboa E Benfica - Futebol SAD. 
